MCCLURE. G. M. G. (1987) Suicide in England and Wales, 1975-1984. British Joumal of Psychiatry. 160, 309-314. Rowlands, R. P. (1995) Deal with self harm in prisons (correspondence). British Medical Journal, 310, 127.

STEVEN F. REID and JOANNe TURNER, Sutton Hospital, Cotswold Road, Sutton SM2 5NF

\section{Working with young offenders: a contribution to forensic training in child psychiatry}

Sir: Specialist forensic training posts in child psychiatry are on the increase. However, in a survey of all child and adolescent psychiatry training schemes in the United Kingdom. Reder \& Lucey (1990) found that training with regard to young offenders was virtually absent. The rise in juvenile crime rates, together with a contraction in services equipped to deal with antisocial young people, have led to increasing concern about the health of young offenders, particularly regarding suicides among young offenders and about a core group of recidivist offenders.

There is therefore a need for specialist training placements which include involvement with young offenders. One such placement exists in North West Thames. The post is equally divided between a children and families department and the regional forensic out-patient department and includes an attachment to Feltham Young Offenders Institution (YOI).

The placement offers unique opportunities. The modes of presentation of disorders and the difficulties faced in treating them can be seen. An insight into the lives of young offenders is gained which provides a valuable understanding of the routes they have followed into crime. The trainee can begin to comprehend the influence of a prison environment on prisoners and on therapeutic relationships through experience of the establishment and knowledge of the Home Office.

With the increasing role of child and adolescent psychiatrists in the assessment and management of young offenders, this area of training can no longer be ignored. Such a placement is time efficient and provides unique training opportunities. It is strongly recommended to senior registrars interested in forensic adolescent psychiatry and would provide an important adjunct to any broadbased training scheme for senior registrars in child and adolescent psychiatry.
REDER, P. \& LUCEY, C. (1990) Child and adolescent psychlatry training schemes: recent developments. Psychiatric Bulletin. 14. 615-617.

A. J. HiLl-SMrTH, North West Thames Child Psychiatry Training Scheme, Adolescent Unit, Hill End Hospital, St Albans, Herts ALA ORB

\section{Severe hypertension associated with risperidone withdrawal}

Sir: We wish to report a case of severe hypertension associated with a rapid discontinuation of risperidone.

A 29-year-old man of mixed African and English origin with a nine year history of schizophrenia was admitted after he had been harassing residents at his hostel and expressing delusions. He had stopped his maintenance medication six months previously.

On arrival he was hostile and thought disordered. Blood pressure was 130/80. He was given oral chlorpromazine and a haloperidol decanoate depot of $200 \mathrm{mg} \mathrm{2-}$ weekly. Continuing disturbed behaviour led to first clonazepam (day 12, increasing gradually to $4.5 \mathrm{mg}$ per day) and then risperidone (day $21,1 \mathrm{mg}$ bd increasing to $4 \mathrm{mg} \mathrm{bd}$ ) being started. Threats and an assault led to droperidol being added on day 23 of admission (increasing gradually to $30 \mathrm{mg}$ tds).

On day 29 of admission he became still more aggressive and a decision was made to stop his clonazepam and risperidone. He was moved to a regional secure unit the following day after being given sodium amytal $500 \mathrm{mg}$ intramuscularly.

On arrival he was surprisingly calm and cooperative. His blood pressure was $230 / 150$ and pulse $100 / \mathrm{minute}$. He had a frontal headache, but there were no clinical abnormalities that could explain the hypertension. Twenty-four hours later his blood pressure had fallen to $165 / 115$ and at 72 hours normalised at $125 / 90$. Investigations failed to provide an explanation for the hypertensive episode, indeed the only abnormality was a urine drug screen positive for cannabis.

Neither sodium amytal nor benzodiazepines have been reported to cause hypertension, and cannabis actually lowers standing blood pressure (Goodman \& Gilman, 1985). Risperidone blocks $D_{2}$, alpha $a_{1}$ and $5-\mathrm{HT}_{2}$ receptors and could have contributed to the hypertensive episode described in this patient, 